(December 21, 1940)

\title{
WEIGHTS OF COAL
}

This letter Circular has been prepared to supply information freouently requested of the Bureau. The reader is cautioned that the data presented herein are only averase values, and that in the case of any particular delivery of coal the actual weight per cubic foot, the actual number of cubic feet per ton, and so forth, may difter materially from the average values given.

These average values may satisfactorily be used for calculating. the approximate size of bin required to contain a given number of tons of coal, the approximate number of tons of coal which a given bin will.contain, and the approximate weight of a measured amount of coal. Relatively large shortages can be detected by computing the weights of deliveries, and computed weights may properly be used by a purchaser as a basis of complaint to the weights and measures official; however, such evidence alone would in all probability not be accepted by a court, and exact information can be procured only by actually weighing the coal comprising a delivery.

The average weight per cubic foot of anthracite (hard coal) varies with the size into which the coal is broken, and with the kind of coal or the vein from which the coal comes. The latter variation is nearly 10 percent, but the figures given below are averages of several different varieties, and probably represent average coal purchased within 2 or 3 percent. Redesh coal is somewhat lighter than that giving white ashes, and accordingly two sets of values are given.

Averege weights of Anthracite in Founds per Cubic Foot

\begin{tabular}{|c|c|c|}
\hline \multirow[t]{2}{*}{ Size } & \multicolumn{2}{|c|}{ Weight per Cubic Foot } \\
\hline & $\begin{array}{l}\text { White-3sh } \\
\text { coal }\end{array}$ & $\begin{array}{c}\text { Red-ash } \\
\text { coal }\end{array}$ \\
\hline & pounds & pounds \\
\hline 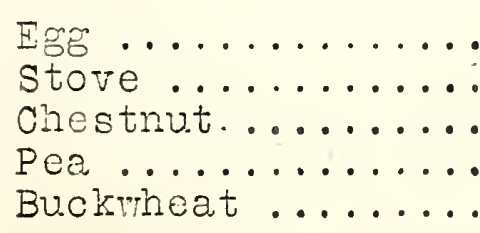 & $\begin{array}{l}57.0 \\
\quad 56.5 \\
5 \\
55.5 \\
5 \quad 53.5\end{array}$ & $\begin{array}{l}53.0 \\
52.5 \\
52.0 \\
51.0 \\
50.5\end{array}$ \\
\hline
\end{tabular}


Based upon the foregoing values, the average numbers of cubic feet of anthracite per 2,000-pound ton (net or short ton) and per 2240-pound ton (gross or long ton), for whiteash and for red-ash coal in each of the listed. sizes, are as follows:

Average Volumes of Anthracite in Cubic Feet per Ton

\begin{tabular}{|c|c|c|c|c|}
\hline \multirow[t]{2}{*}{ Size } & \multicolumn{2}{|c|}{$\begin{array}{c}\text { Cubic Feet } \\
\text { per 2,000-1b Ton }\end{array}$} & \multicolumn{2}{|c|}{$\begin{array}{l}\text { Cubic Feet } \\
\text { per } 2,240-1 b \text { Ton }\end{array}$} \\
\hline & $\begin{array}{l}\text { White-asin } \\
\text { coal }\end{array}$ & $\begin{array}{c}\text { Red-ash } \\
\text { coal }\end{array}$ & $\begin{array}{l}\text { White-ash } \\
\text { coal }\end{array}$ & $\begin{array}{l}\text { Red-ash } \\
\text { coal }\end{array}$ \\
\hline & cu. $f t$ & cu $f t$ & cu ft & cu ft \\
\hline 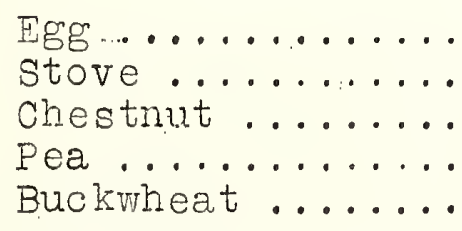 & $\begin{array}{l}35 \cdot 1 \\
35 \cdot 4 \\
36.0 \\
37 \cdot 4 \\
37.7\end{array}$ & $\begin{array}{l}37.7 \\
38.1 \\
38.5 \\
39.2 \\
39.6\end{array}$ & $\begin{array}{l}39 \cdot 3 \\
39 \cdot 6 \\
40 \cdot 4 \\
41 \cdot 9 \\
42 \cdot 3\end{array}$ & $\begin{array}{l}42.3 \\
42.7 \\
43.7 \\
43.9 \\
44.4\end{array}$ \\
\hline
\end{tabular}

Based upon the average weigits per cubic foot and upon the relation between the cubic foot ( 1,728 cubic inches) and the stricken bushel (2,150.42 cubic inches), the average weights of anthracite per stricken bushel (level full) are as follows:

Average weights of Anthracite in Pounds per stricken Bushel

\begin{tabular}{|c|c|c|}
\hline \multirow[t]{2}{*}{ Size } & \multicolumn{2}{|c|}{ Weight per Stricken Bushel } \\
\hline & $\begin{array}{c}\text { White-ash } \\
\text { coal }\end{array}$ & $\begin{array}{c}\text { Red-ash } \\
\text { coal }\end{array}$ \\
\hline & pounds & pouncis \\
\hline 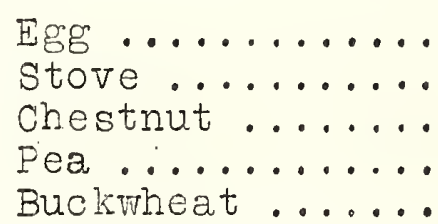 & $\begin{array}{l}70.9 \\
70.3 \\
69.1 \\
66.6 \\
66.0\end{array}$ & $\begin{array}{l}66.0 \\
65.3 \\
64.7 \\
63.5 \\
62.8\end{array}$ \\
\hline
\end{tabular}

The weights of bituminous (comon soft) coals vary even more than those of anthracite, according to the locality from which the coal comes. Such weights range from 47 to 55 pounds per cubic foot. These values correspond to 42.6 to 36.4 cubic feet per 2,000-pound: ton, and to 47.7. to 40.7 cubic feet per 2,240-pound ton; and to 58.5 to. 68.4 pounds per stricken bushel. 